\title{
FATAL ALUMINIUM PHOSPHIDE POISONING IN FAYOUM GOVERNORATE, EGYPT (2012-2019)
}

\author{
Marwa Ali Mwaheb ${ }^{1}$, Safaa Khamis Hassan ${ }^{2}$ \\ ${ }^{1}$ Assistant Professor of forensic medicine and clinical toxicology Department \\ ${ }^{2}$ Assistant Professor of Public Health and Community Medicine \\ 1,2 Faculty of Medicine (Fayoum University) \\ Corresponding author: Marwa Ali Mwaheb, Forensic Medicine and Clinical \\ Toxicology Department, Faculty of Medicine. (Fayoum University, Cairo). \\ 01006267354; \\ marwa.mwaheb@yahoo.com
}

Date of submission: 15 April 2020

Revised at: 4 May 2020

Accepted at: 12 May 2020

\begin{abstract}
Background: Aluminium phosphide (AlP) is an insecticide and rodenticide used to shield put away grains from rodents and other household bugs. Aim of work: Surveying the death pace of Aluminium Phosphide hurt cases guaranteed to the Forensic Medical Authority (FMA) at Fayoum Governorate. Method: A crosssectional research assessed deaths from ALP poisoning in Fayoum Governorate between June 2012 and June 2019 were evaluated reflectively and included into the present study $(n=96)$. The cases were assessed according to: age, gender, residence, single or married, cause of suicide and autopsy findings. Results: Majority of studied cases were females $(71.9 \%)$, and the mean age of the decedents $29 \pm 9.9$ ranged (from 20 to 60 years old) whears 71 (74\%) of the dead were aged between (20 and 30 years old). Nearly, half of the deaths were from Fayoum district (46.9\%), followed by Sinnoris district (21.9\%). The distribution of deaths indicated an increase in number of deaths especially in recent years. The study showed that $24 / 96(25 \%)$ of the cases were registered in 2017. On 2018, number of deaths increased to 35/96 (36.5\%). Judging from the case history, all deaths in the study were (100\%) suicidal attempts. The majority of deaths mentioned in the study 69/96 (71.9\%) were with unknown causes. Conclusion: Mortality because of AlP harming was the most elevated reason of death in youthful females and the most common self-destructive element. Local authorities must to put restrictions on purshases ALP in open sales.
\end{abstract}

Keywords: Aluminium phosphide, poisoning, mortality

\section{INTRODUCTION}

poisoning is a mutual medicosocial problem that represents a major health challenge all over the world, and depletes valuable health service resources with considerable high morbidity and mortality. Aluminium phosphide (AIP) is a wellknown, efficacious insecticide and rodenticide, (Mehrpour et al., 2012) and is one of the most ordinarily used pesticides readily available in local stores though its sale is illegal (Bogle, 2006 and Shadnia et al., 2009). It does not alter seed viability and leaves no residue on protected grains, yet evokes outrageous lethal impacts to people for which no convenient antidote is available. Mortality from AlP poisoning ranges from $37 \%$ to $100 \%$. Exposition is either accidental, occupational or by suicidal intention (Bumbrahet al., 2014 and Bhalla A and Singh, 2015). 
Premeditated and incidental oral ingestion of the metal phosphides isn't uncommon in certain parts of the world and many cases of acute premeditated poisoning have been documented by a mortality rate of higher than $50 \%$ (Singh et al., 1985 and Shadniaet al., 2008). Ingestion of phosphides may instigate serious gastrointestinal irritation, cardiovascular collapse, acute neuropsychiatric troubles, respiratory and renal failure, and late hepatic harm may lead to death within 4 days, but most of cases died within 24 hours or less. Diagnosis of phosphine/phosphide poisoning is normally based on the history and clinical side effect. Blood and urine samples cannot be used for phosphine detection, because the exact mechanism of toxicity of phosphine/phosphide poisoning is not clear in human beings yet, and no particular treatment or antitoxin is accessible so far (Fatma et al., 2019).

This first research of Aluminium phosphide poisonings reported to the Medicolegal Department of Ministry of justice at Fayoum governorate .We expect the data and analysis to contribute significantly in reinforcement preventive measures against Aluminium phosphide poisoning-induced mortality and morbidity. The study aimed to record numbers of issues during the approximate period of 2012 to 2019 by demographic and geographic variables and also gain some ideas of trends and some perspectives on the complex issues of this serious problem (e.g., expanded controls from policymakers, open mindfulness and instruction).

\section{MATERIAL AND METHODS}

$\underline{\text { Study Design and setting }}$
A cross-sectional study evaluated deaths from ALP poisoning in Fayoum Governorate. All cases of Aluminium Phosphide poisoning claims referred to the Forensic Medical Authority (FMA) at Fayoum Governorate, between June 2012 and June 2019 were reviewed retrospectively and included into the present study $(\mathrm{n}=96)$, which shows deaths reported due to suicidal attempts $\quad(n=96)$, while other causes were excluded. It was implemented in Fayoum Governorate, which lying in Middle Egypt, about 100 kilometers (62 miles) southwest of Cairo. The total population of Fayoum Governorate is 3.170 .150 inhabitants in January, 2015 with $22.5 \%$ urban and $77.5 \%$ rural population, according to the Central Agency for Public Mobilization and Statistics (CAPMAS). Fayoum Governorate was divided into 6 districts: (Fayoum, Etsa, Tamiya, Sinnoris, Youssef Sadiek, Abshoay). Each district is composed of groups of villages representing Fayoum rural area. The main capital of the governorate is Fayoum city which is considered the urban area (CAPMAS, 2015)

Information was gained from documents of Forensic Medical Authority at Fayoum Governorate (FMA). The cases were evaluated according to the following factors: age, gender, residence, single or married, cause of suicide and autopsy findings. All deaths were with suicidal endeavor $(100 \%)$ with froth around the mouths, and garlic odor as reported. Presence of phosphine gas in stomach in some cases by toxicological examination.

Statistical Analysis

- Data were collected, coded and analyzed using Statistical Package for Social Science (SPSS version 16. Chicago IL, USA). Simple descriptive analysis in the form of means and standard deviations for numerical data, Frequencies and percent for qualitative 
data. Non-parametric tests (chi-square) were used to find its association with other factors. $\mathrm{P} \leq 0.05$ was considered statistically significant.

\section{RESULTS}

The demographic characteristics of 96 deaths of Aluminum phosphate poisoning over the period from 2012 to 2019 were collected from reports of the Forensic Medicine Authority, most of the deaths 74/96 (77.1\%) occurred in the period from 2016 to 2019, and majority of them were females (71.9\%), while the mean age of the decedents $29 \pm 9.9$ ranged from (20 to 60 years) whears71 (74\%) of the dead persons were aged between 20 to 30 years old. Nearly half of deaths from Fayoum district $(46.9 \%)$ followed by Sinnoris district $(21.9 \%)$. About two third of the deaths were singles $(62.5 \%)$ as in table (1).

The distribution of deaths indicates an increase in number of deaths in recent years from 2016 to 2019 especially in the year 2017; the deaths were $24 / 96(25 \%)$. In the year 2018 there were 35/96(36.5\%) deaths as in fig (1). Majority of deaths 69/96 $(71.9 \%)$ were with unknown causes. Autopsy examination showed that $6.2 \%$ of the victims were not virgin and $4.2 \%$ of them were pregnant without marriage and presence of phosphine gas in stomach by $4.2 \%$ table (2) and fig (2). There were more deaths among the youth in the age from 20 to 30 years old. The studied cases were all among single people, people with social troubles, among females and rural population with significant difference $(\mathrm{p}=<0.05)$ table (3). This study also recorded that the most of the victims $(92.7 \%)$ had cardiovascular collapse and $84.4 \%$ had abdominal pain. Nearly half $(45.8 \%)$ of them had vomiting $32.3 \%$ of them were with dyspnea, $20.8 \%$ were with coma and only $(8.3 \%)$ of them showed cyanosis in table (4). Death from aluminium phosphide poisoning $64 / 96(66.67 \%)$ of the victims died after 2 hours of admission and 32/96 $(33.33 \%)$ died immediately as illustrated in fig (3).

In fig (4) recorded the distribution of first aid treatment ( gastric lavage ) to the patients in hospitals by residence 41/96 (42,7\%) of the victims had done gastric lavage more than half of the procedure had been applied at Fayoum district hospital by $53.66 \%$ followed by snoris district hospital by $19.51 \%$. 
Table (1): Demographic characteristics and distribution of deaths related to Aluminum phosphate poisoning in Fayoum governorate from 2012 to 2019

\begin{tabular}{|c|c|c|}
\hline Characters & N (96) & $\%$ \\
\hline Sex & 27 & 28.1 \\
Male & 69 & 71.9 \\
Female & & \\
\hline Age & 71 & 74 \\
20-30 years old & 25 & 26 \\
$\geq 40$ years & & \\
\hline Residence & 45 & 46.9 \\
Fayoum & 10 & 10.4 \\
Abshoway & 16 & 16.7 \\
Etsa & 4 & 4.2 \\
Tamia & 21 & 21.9 \\
Snoris & 60 & 62.5 \\
\hline marital status & 36 & 37.5 \\
Single & 22 & 22.9 \\
Married & 74 & 77.1 \\
\hline Year interval & & \\
2012-2015 & & \\
2016-2019 & & \\
\hline
\end{tabular}

Table (2): Case History Distribution and Autopsy of Aluminum Phosphide

Poisoning-Related Deaths 2012 to 2019 (total number 96)

\begin{tabular}{|l|l|}
\hline Number (96) & $\%$ \\
\hline Case History & \\
Psychotic disorders & $5(5.2)$ \\
Social troubles (with family or divorce) & $22(22.9)$ \\
Unknown causes & $69(71.9)$ \\
\hline Autopsy & \\
Abrasion and bruises & $10(10.4)$ \\
Not virgin (single females) & $6(6.2)$ \\
Pregnant (single females) & $4(4.2)$ \\
Phosphine gas in stomach & $6(6.2)$ \\
No finding & $70(73)$ \\
\hline
\end{tabular}


Table (3): Factors related to mortality from ALP poisoning

\begin{tabular}{|c|c|c|c|c|c|}
\hline Characters & $\begin{array}{l}2012 \text { to } 2015 \\
(\mathrm{~N}=22) / \%\end{array}$ & $\begin{array}{l}2016 \text { to } 2019 \\
(\mathrm{~N}=74)\end{array}$ & $\mathbf{X}^{2}$ & Odds ratio CI (95\%) & P value \\
\hline $\begin{array}{l}\text { Sex } \\
\text { Males (27) } \\
\text { Females (69) }\end{array}$ & $\begin{array}{c}10(37) \\
12(17.4)\end{array}$ & $\begin{array}{c}27(63) \\
69(82.6)\end{array}$ & 4.420 & 2.794(1.029-7.586) & $0.039 *$ \\
\hline $\begin{array}{l}\text { Age } \\
20 \text { to } 30 \text { years }(\mathbf{7 1}) \\
>=40 \text { years old }(25)\end{array}$ & $\begin{array}{c}14(19.7) \\
8(32)\end{array}$ & $\begin{array}{c}57(80.3) \\
17(68)\end{array}$ & 1.579 & $0.522(0.188-1,453)$ & 0.209 \\
\hline \begin{tabular}{lc}
\multicolumn{2}{l}{ Residence } \\
urban $\quad 45$ \\
rural & 51 \\
\end{tabular} & $\begin{array}{c}15(33.3) \\
7(13.7)\end{array}$ & $\begin{array}{l}30(66.7) \\
44(86.3)\end{array}$ & 5.203 & $3.143(1.143-8.630)$ & $0.023 *$ \\
\hline $\begin{array}{l}\text { Marriage } \\
\text { Single (60) } \\
\text { Married (36) }\end{array}$ & $\begin{array}{l}14(23.3) \\
8(22.2)\end{array}$ & $\begin{array}{l}46(76.7) \\
28(77.8)\end{array}$ & .016 & $1.065(0.397-2.860)$ & 0.900 \\
\hline $\begin{array}{l}\text { social troubles } \\
\text { Yes } 22 \\
\text { No } 74\end{array}$ & $\begin{array}{l}4(18.2) \\
18(24.3)\end{array}$ & $\begin{array}{l}18(81.9) \\
56(75.7)\end{array}$ & 0.362 & $1.446(0.433-4.834)$ & 0.547 \\
\hline
\end{tabular}

Table (4): clinical findings of the patients after arrival to the hospital (96 fatalities)

\begin{tabular}{|l|l|l|}
\hline Clinical findings & NO of patients & Percentage (\%) \\
\hline Cardiovascular collapse & 89 & 92.7 \\
\hline Abdominal pain & 81 & 84.4 \\
\hline Vomiting & 44 & 45.8 \\
\hline dyspnea & 31 & 32.3 \\
\hline coma & 20 & 20.8 \\
\hline cyanosis & 8 & 8.3 \\
\hline
\end{tabular}

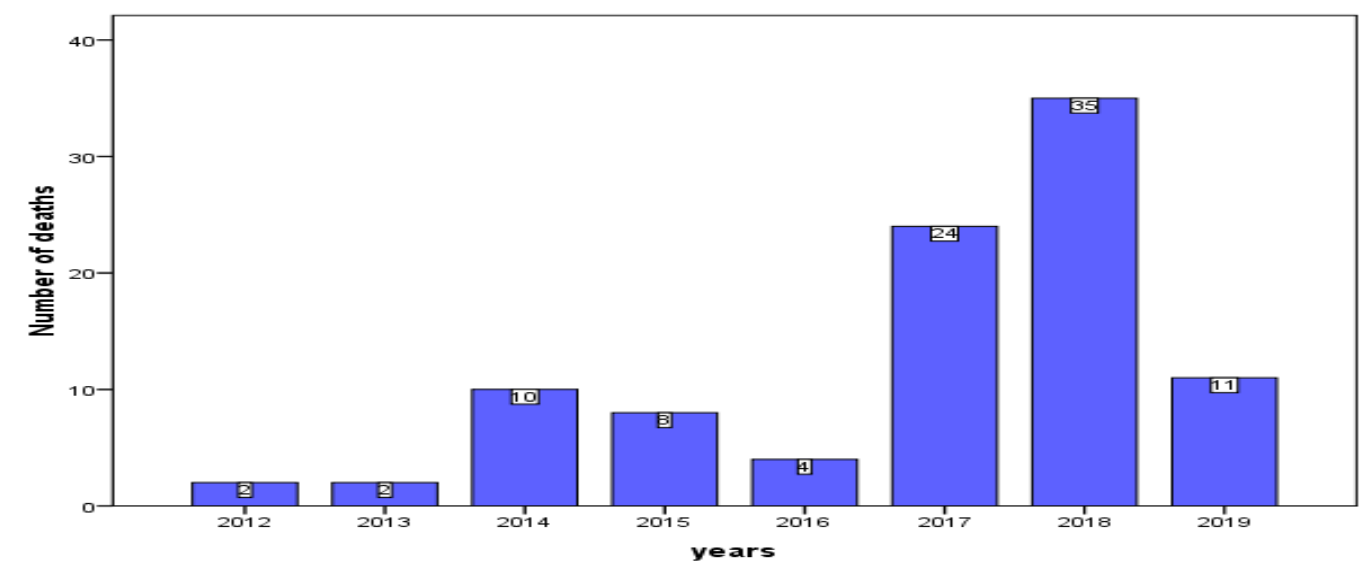

Figure (1): Distribution of deaths related to Aluminum phosphate poisoning in Fayoum governorate over the years from 2012 to 2019 


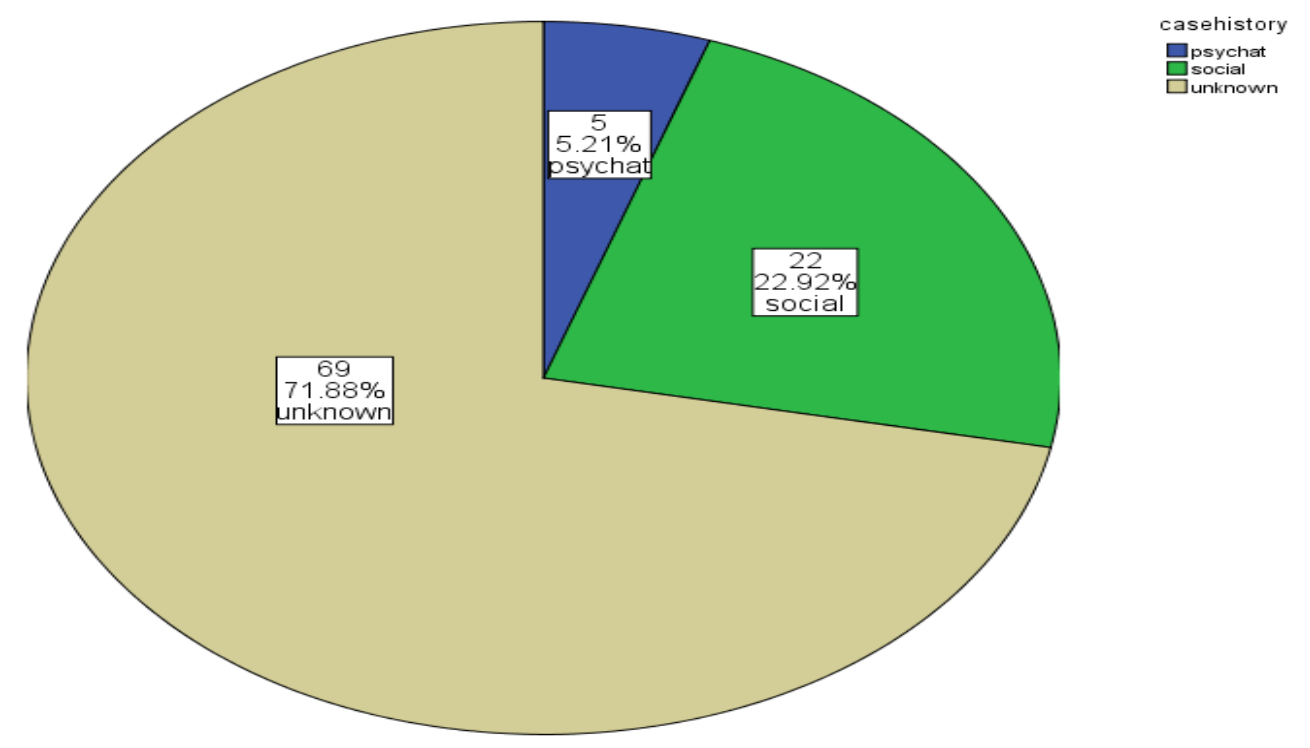

Figure (2): Distribution of causes of suicidal attempts as reported from the case history

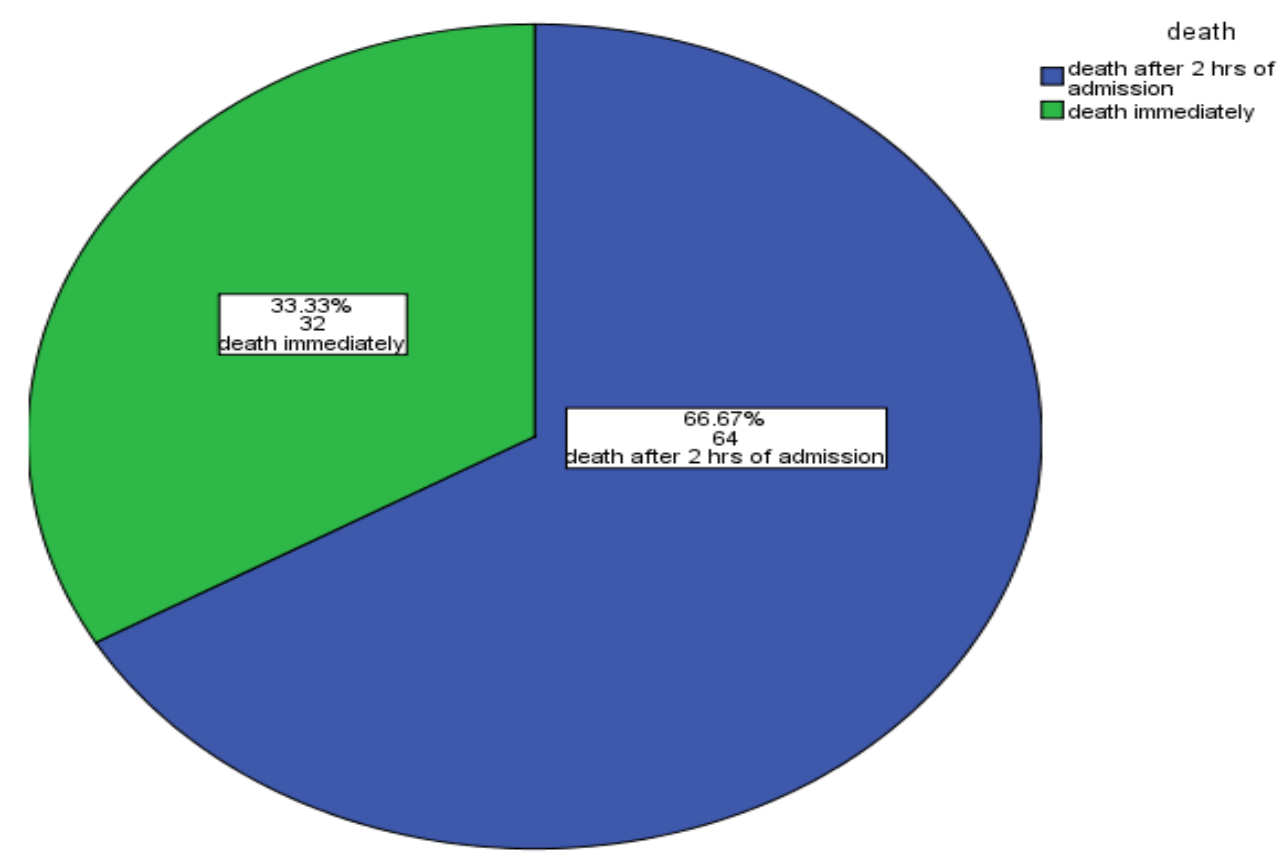

Figure (3): Distribution time interval between onset of overdose, admission to hospital and immediately death. 


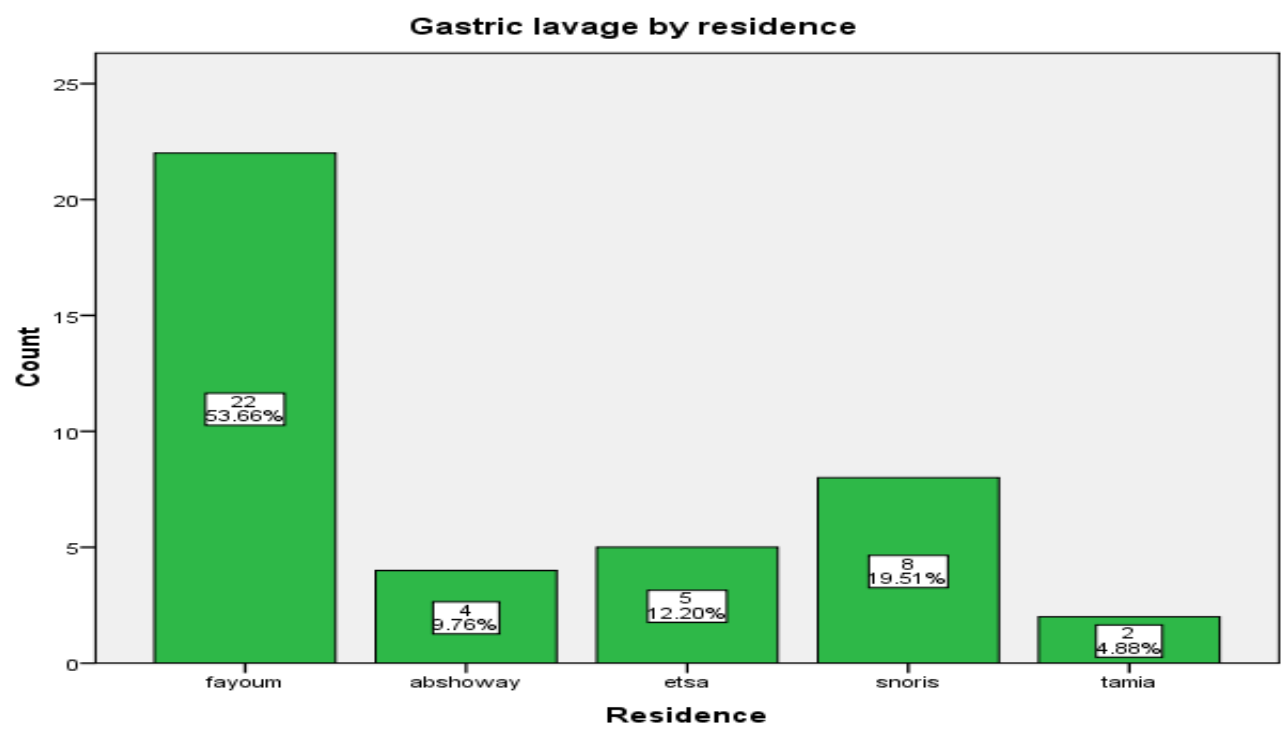

Figure (4): Distribution of first aid treatment (gastric lavage) of patients in hospital related to residence.

\section{DISCUSSION}

In recent years, frequency of intense aluminium phosphide harming (ALP) an amazingly dangerous substance has a high mortality. Phosphine, the dynamic part, hinders the mitochondrial cytochrome oxidase and the cell oxygen usage, disrupting at the end the normal mitochondrial Activity (Valmas et al., 2008 and Karami et al., 2013).

The occurrence of AlP harming in Egypt began to increment, and records of patients started to appear for a sensible extent (Hasabo, 2015). The present study was completed to assess aluminium phosphide harming related passing in Fayoum Governorate over the 7 earlier years, this research indicated expanded number of (ALP) related passing because of selfdestructive endeavors by 74/96 (77.1 $\%$ ) in 2016 to 2019 versus 22/96 ( $22.9 \%$ ) in 2012 to 2015 particularly in 2017 and 2018 separately. This was reliable with numerous examinations led in Egypt, Iran and India (Hawton and Van, 2009 and Singh et al.,
2014), which might be explained by the wide abuse and the easy accessibility to aluminium phosphate tablets in the developing countries (Mann, 2005).

The suicidal causes for the unfortunate casualties archived in this research were for the most part obscure 69/96 (71.9\%). According to the study, $22.9 \%$ of causes credited to social inconveniences in the family, divorce and fornication especially if it led to pregnancy. We also discovered that $5.21 \%$ of the deaths were due to psychiatric disorders. This might be due to increasing numbers of unreported causes of suicide cases because of social embarrassment. Anyway there are numerous examinations which portrayed solid relationship between suicide mortality and mental or physical disorder (Hegerl et al., 2009, Dias et al., 2014 and El Hangouche et al., 2017).

Post-mortem examination demonstrated that $6.2 \%$ of not married victims were not virgins and $4.2 \%$ of 
them were pregnant without marriage. Over the period from 2012 to 2019 , numbers of studied deaths identified with phosphate harming expanded particularly in the period from 2016 to 2019. There was more passing among the adolescents aging from 20 to 30 years old, this concurs with other announced study that most of passing was $32 \%$, and $62 \%$ of the patients were more youthful than 20 years old. In a comparative research, 28 cases with mean (SD) age of 24 years old (11) long periods of AIP harming conceded in Morocco between January 1992 and December 2002(Hajouji et al., 2006). Another documented study in Iran revealed a general mortality of $31 \%$, with half being males with a mean time of 27.1 years (Afshar et al., 2015). Most of the patients were somewhere in the range of 20 and 40 years of age. Another Iranian research revealed that $93 \%$ of cases were self-harming with a self-destructive expectation which concurs with this study that the most common reason for harming is suicidal (Soltaninejad et al., 2012).

Autopsy reports can make significant data about the utilization of lethal substances for various purposes. Phosphine gas in stomach, foam around the mouths, and garlic scent in AlP harming cases were accounted for by Forensic Medical Authority in the present seeking. The outcomes are in concurrence with those of revealed wicked exudate leaving the (Jain et al., 2005 and Bumbrah et al., 2012), mouth and nose of youngsters harmed with AlP. Some vital organs were observed to be congested in the present investigation; this finding had likewise been seen in previous studies (Sinhaet al., 2005 and Abder-Rahman, 2009).

In trial studies, phosphine can initiate oxidative harm in liver, lungs, and brain of rats( Arora et al.,1995) Histopathological examination of vital organs demonstrated congestion, edema, and leukocyte invasion particularly in lungs, kidneys and adrenal, which recommend cell hypoxia in the research of discoveries affirm presence of congestion in the liver and lungs of rodents exposed to AlP. Previous studies recommend that a combination of vitality deficiency and oxidative pressure could legitimize dialogue about the pathophysiologic impacts of phosphine poisonous toxicity (Anand et al., 2012).

In this research also documented, most of the victims $(92.7 \%)$ had cardiovascular collapse and $84.4 \%$ had abdominal pain. Nearly half $(45.8 \%)$ of them had vomiting $32.3 \%$ of them were with dyspnea, $20.8 \%$ were with coma and only $(8.3 \%)$ of them showed cyanosis which was agreement with other research in Tahran showed In our study, $28.13 \%$ of patients showed loss of consciousness on admission time. About $78 \%$ of patients had cardiovascular manifestation on admission time with 96\% (Ola et al., 2017).

The shortage of a specific antidote is a major concern when treating AIP poisoning. Of course, several other (mainly supportive) therapeutic choices might be tried, including gastric lavage which showed that $41 / 96(42,7 \%)$ of the victims had done gastric lavage more than half of the procedure had been applied at Fayoum district hospital by $53.66 \%$ followed by snoris district hospital by $19.51 \%$,that coincide with other research recorded that is only treatment is supportive like including gastric washing with sodium bicarbonate (alternatively the potassium permanganate), hydration, oral administration of charcoal, hyperbaric oxygen, Intravenous magnesium sulphates, treatment of acidosis, fluid resuscitation, vasopresors, digoxin and trimetazidine have been tried as well, 
particularly when cardiogenic shock overwhelms the clinical picture (Mofrih et al., 2019).

\section{CONCLUSION}

Information obtained from this recorded study demonstrated that the pattern of AlP casualty is continuously expanding in Fayoum Governorate .The mortality because of AlP harming influences youthful females more than males. The issue winds up influencing both rural and urban individuals, single or married.

\section{LIMITATIONS}

It is a retrospective data collection and the general little example estimate with deficiency of data on the proven amount of AlP and its route of exposure. Also, there is absence of data on the exact time tardiness between admission of the patients and inception of treatment. The scarcity of a specific antidote adds further difficulties to every one of these exposures. The requirement for general wellbeing plans going for counteractive action, awareness, and conceivably the substitution of phostoxin or other aluminium phosphide pesticides with less risky is detailed.

\section{REFRENCES}

\section{Abder-Rahman HA. (2009):}

Aluminium phosphide fatalities at mild exertion in asymptomatic children: a clue to understand the variations of the autopsy findings . J Forensic Leg Med; 16:312315.

Afshar E, Maryam Akhgari, and Fariba Sardari Iravani.(2015): Aluminium Phosphide Poisoning-Related Deaths in Tehran, Iran, 2006 to 2013. Medicine J. 94(38); 1-7

Anand R, Kumari P, Kaushal A, et al.( 2012): Effect of acute Aluminium phosphide exposure on rats: a biochemical and histological correlation. Toxicol Lett.215: 62-69.

Arora B, Punia RS , Kalra R, et al. (1995) : Histopathological changes in Aluminium phosphide poisoning. J IndianMed Assoc. 93:380-381.

Bhalla A and Singh S.( 2015): Aluminium phosphide poisoning. J Mahatma Gandhi Inst Med Sci.; 20(1):15.

Bumbrah GS, Krishan K, Kanchan T, et al.( 2012): Phosphide poisoning: a review of literature. Forensic Sci Int.214:1-6.

CAPMAS.(2015): $\quad$ Population Estimates By Sex \& Governorate 1/1/2015" available http://www.msrintranet.capmas. gov.eg/pdf/EgyptinFigures2015/ EgyptinFigures/Ta bles/PDF/1/pop.pdf. accessed 2017.

Dias D, Mendonça MC, Real FC, et al.( 2014):Suicides in the Centre of Portugal: seven years analysis. Forensic Sci Int; 234:22-28.

El Hangouche AJ, Fennich $H$, Alaika O, Dakka T, Raissouni Z, Oukerraj L, et al.( 2017): Reversible Myocardial Injury and Intraventricular Thrombus Associated with aluminium Phosphide Poisoning. Case Reports. Cardiol.3(2);1-6.

Fatma M,Walaa $K$ and Heba K.( 2019): Early L-canitine Therapy in Sever Acute Aluminium phosphide poisoning: Arandom Controlled clinical Trial. Egypt J. Forensic Sci. Appli. Toxicol.vol 19(4):147-164.

Hajouji M, Oualili, L, Abidi, K, Abouqal, $\mathbf{R}$, Kerkeb, $O$ and Zeggwagh, AA. (2006): Severity factors of aluminium phosphide 
poisoning (Phostoxin $®)$. Ann Fr Anesth Reanim; 25: 382-385.

Hasabo GH (2015): Aluminium phosphate, a serious killer in Egypt, case report Journal of Forensic, Toxicology and Medicolegal Analysis, 1 (1 ): 6-7

Hawton $K$ and Van K. ( 2009): Suicide. Lancet; 373:1372-1381.

Hegerl U, Wittenburg L, Arensman E, et al. Optimizing suicide prevention programs and their implementation in Europe (OSPI Europe): an evidence-based multilevel approach. BMC Public Health 2009; 9:428-436.

Jain AK, Nigam M, Garg SD, et al. (2005): Aluminium phosphide poisoning, autopsy findings. J Ind Acad Forensic Med (JIAFM).; 27:35-39.

Karami S, Jafari A and Abdollahi M.( 2013): Comprehensive review of the mechanistic approach and related therapies to cardiovascular effects of Aluminium phosphide. Int $\mathbf{J}$ Pharmacol.; 9:493-500.

Mann JJ, Apter A, Bertolote J, et al.( 2005):Suicide prevention strategies: a systematic review. JAMA; 294:2064-2074.

Mehrpour O, Jafarzadeh $M$ and Abdollahi M.( 2012): A Systematic Review of aluminium Phosphide Poisoning. Arch Ind Hyg Toxicol., 63(1):61-73.

Bogle RG.( 2006): Aluminium phosphide poisoning. Emerg Med J.; 23(1): 1-3.

Mofrih H, Situhom E and Eman S. (2019): Pattern and predictors of death from Aluminium and Zink phosphide poisoning: A two years prospective study. Egypt J. Forensic Sci. Appli. Toxicol. vol 19(2):73-86.
Ola Abdel Hady S , Fatama K and Dalia N.( 2017): Management of acute Aluminium phosphide toxicity in rat module with A novel intervention, Atrial of Boric acid, Egypt J. Forensic Sci. Appli. Toxicol. vol 17(2):57-72.

Shadnia S, Sasanian G, Allami P, Hosseini A, Ranjbar A, AminiShirazi N, et al.( 2009): A retrospective 7-years study of aluminum phosphide poisoning in Tehran: Opportunities for prevention. Hum Exp Toxicol. 28(4):209-13. Bumbrah GS, Krishan K, Kanchan T, Sharma $M$ and Sodhi GS.

(2014): Phosphide poisoning: A review of literature. Forensic Sci Int.,(1-3):1-6.

Shadnia, S, Mehrpour, $O$ and Abdollahi, M. (2008): Unintentional poisoning by phosphine released from Aluminium phosphide. Hum Exp Toxicol; 27: 87-89.

Singh Y, Joshi SC, Satyawali V and Gupta A.( 2014): Acute aluminium phosphide poisoning, what is new? Egypt J Intern Med; 26:99-103

Singh, S, Dilawari, JB, Vashist, R, Malhotra, HS and Sharma, BK. (1985): Aluminium phosphide ingestion. BMJ; 290: 1110-1111.

Sinha US, Kapoor AK, Singh AK, et al. (2005):Histopathological changes in cases of aluminium phosphide poisoning. Indian $\mathbf{J}$ Pathol Microbiol. 48:177-180.

Soltaninejad K, Nelson LS, Bahreini SA and Shadnia S.( 2012): Fatal Aluminium phosphide poisoning in Tehran-Iran from 2007 to 2010,The Indian journal of medical science,66(3):65-70 
Valmas N, Zuryn S and Ebert PR.

(2008): Mitochondrial uncouples act synergistically with the fumigant phosphine to disrupt mitochondrial membrane potential and cause cell death. Toxicology. 252(1-3):33-9. 


\section{الملخص العربي}

فوسفيد الألومنيوم هو مبيد حشري ومبيد للقوارض يستخدم لحماية الحبوب من القو ارض والحشرات المنزلية الأخرى. هدف البحث هو دراسة عدد الوفيات لحالات اصابات فوسفيد الالمنيوم التي سجلت في مصلحة الطب الشر عي الشرعي بمحافظة الفيوم. وفي هذا البحث قمنا بدراسة احصائية للوفيات الناجمة عن التسمم فوسفيد الومنيوم في محافظة الفيوم بين يونيو 2012 ويونيو 2019 (عدد الحالات التي تم تسجيلها 96 حاله). تم تقييم الحالات حسب: العمر ، الجنس ، الإقامة ، أعزب أو متزوج ، سبب الانتحار وتشريح الجثة. أظهرت نتائج هذه الدر اسة أن أغلبية الحالات كانت من الإناث (71.9٪) ، ومتوسط عمر المتوفين 29 × 9.9 تر اوحت (من 20 إلى 60 سنة) ، 71 (74\%) من المتوفين تتر اوح أعمار هم بين (20 و 30 سنة) ـ ما يقرب من نصف الوفيات من محافظة الفيوم (46.9٪) ، تليها منطقة سنوريس (21.9٪). و أشار نوزيع الوفيات إلى زيادة في عدد الوفيات خاصة في السنو ات الأخيرة. و أظهرت الدراسة أن 96/24 (25٪) من الحالات تم تسجيلها عام 2017. وفي عام 2018 ، ارتفع عدد الوفيات إلى 96/35 (36.5٪). انطلاقا من تاريخ القضية ، كانت جميع الوفيات في الدراسة (100٪) محاو لات انتحارية. غالبية الوفيات الدذكورة في الدراسة 96/69 (71.9٪) كانت لها أسباب مجهولة. كان معدل الوفيات بسبب تسسم من فوسفسد الومنيوم هو السبب الأكثر ارتفاعًا للوفاة في الإناث الثابات و العنصر الأكثر تدميرًا ذاتيًا. يجب على السلطات المحلية وضع قيود على استخدام فوسفسد الومنيوم في جميع منافذ البيع. 